\title{
KONSEP PENATAAN KOLEKSI MUSEUM UNTUK MEMPERMUDAH PEMAHAMAN WISATAWAN DALAM WISATA EDUKASI ARSIP DAN KOLEKSI PERBANKAN DI MUSEUM BANK MANDIRI JAKARTA
}

\author{
Nuryuda Irdana \\ Program Studi Kepariwisataan, Sekolah Vokasi, Universitas Gadjah Mada \\ nuryudairdana@gmail.com \\ Sthanu Kumarawarman \\ PT Bank Mandiri (Persero) Tbk. Area Yogyakarta \\ kumarawarman.sthanu@gmail.com
}

\begin{abstract}
Museum is one of the element that reserve cultural heritage which connecting people from past to present. Collection management is a way to create museum as a trusted information resources place. As a part of educational tourism, Bank Mandiri Museum administrators have to able to managing archives and collections in the museum. This research used inductive reasoning method. Observation, interview and also literature studies were data collecting methods that used in this research. The results of this research show that the storyline built by Bank Mandiri are the storyline of bank services, operation, documents, securities, facilities and bank equipments from time to time. Whereas for archives and collections management, Bank Mandiri Museum uses three approaches, that are thematic, taxonomic and also chronologic.
\end{abstract}

Keywords: Archive and collection management, storyline, educational tourism, Bank Mandiri Museum

\section{Intisari}

Museum adalah salah satu elemen yang menyimpan warisan budaya yang menghubungkan manusia dari masa lalu ke masa kini. Pengelolaan koleksi merupakan suatu cara untuk mewujudkan museum sebagai tempat sumber informasi. Sebagai bagian dari wisata edukasi perbankan, pengelola Museum Bank Mandiri tentunya harus memiliki kemampuan untuk mengelola arsip dan koleksi yang ada di museum. Penelitian ini menggunakan metode penalaran induktif yang diawali dengan pengumpulan data melalui pengamatan, wawancara dan studi pustaka. Hasil penelitian menunjukkan bahwa beberapa jenis alur cerita yang dibangun dan dimunculkan oleh Museum Bank Mandiri adalah alur pembelajaran pelayanan bank, alur pembelajaran operasional bank, serta alur pembelajaran dokumen, surat berharga, fasilitas dan peralatan bank dari masa ke masa. Sedangkan untuk penataan arsip dan koleksi, Museum Bank Mandiri menggunakan pendekatan gabungan dari tiga pendekatan, yaitu pendekatan tematik, pendekatan taksonomik, dan pendekatan kronologi.

Kata kunci: Penataan arsip dan koleksi, alur cerita, wisata edukasi, Museum Bank Mandiri 


\section{PENDAHULUAN}

Museum adalah salah satu elemen yang menyimpan warisan budaya yang menghubungkan manusia dari masa lalu ke masa kini. Warisan budaya tersebut adalah bukti peradaban manusia yang telah melewati sebuah proses sosial (Ardiwidjaja, 2013:1). Musyawarah umum ke-11 (11 th General Assembly) International Council of Museum (ICOM) tahun 1974 di Denmark, mengemukakan bahwa museum memiliki fungsi sebagai berikut : (1) Pengumpulan dan pengamanan warisan alam dan budaya, (2) Dokumentasi dan penelitian ilmiah, (3) Konservasi dan preservasi, (4) Penyebaran dan pemerataan ilmu untuk umum, (5) Pengenalan dan penghayatan kesenian, (6) Pengenalan kebudayaan antardaerah dan antarbangsa, Visualisasi warisan alam dan budaya, (8) Cermin pertumbuhan peradaban umat manusia, dan (9) Pembangkit rasa takwa dan bersyukur kepada Tuhan Yang Maha Esa (Direktorat Museum Departemen Kebudayaan dan Pariwisata, 2008).

Selanjutnya pada Musyawarah umum ke-22 (22th General Assembly) International Council of Museum (ICOM) tahun 2007, ICOM mendefinisikan museum sebagai lembaga, tempat penyimpanan, perawatan, pengamanan, dan pemanfaatan benda-benda bukti materil hasil budaya manusia serta alam dan lingkungannya guna menunjang upaya pelindungan dan pelestarian kekayaan budaya bangsa. Untuk itu maka museum harus memiliki dan mengelola koleksi. Pengelolaan koleksi merupakan suatu cara untuk mewujudkan museum sebagai tempat sumber informasi. Benda koleksi tidak hanya diletakan begitu saja, tetapi juga perlu ditata dan direncanakan penempatannya agar mudah dipahami oleh pengunjung (Direktorat Museum Departemen Kebudayaan dan Pariwisata, 2008).

Jakarta sebagai ibukota negara ternyata juga kaya akan wisata museum.
Menurut Gubernur DKI Jakarta, saat ini terdapat 142 museum di Propinsi DKI Jakarta (Kompas, 2016).

Menurut Dinas Komunikasi, Informatika dan Statistik Pemerintah Provinsi Jakarta (2017), jumlah kunjungan wisatawan ke museum di lingkungan Dinas Kebudayaan dan Pariwisata Jakarta tahun 2015 adalah sebesar 3,185,924 wisatawan yang terdiri dari 3,068,642 wisatawan nusantara dan 117,282 wisatawan mancanegara. Jumlah kunjungan tersebut menunjukkan bahwa minat wisatawan terhadap objek wisata museum masih tinggi. Kondisi ini juga didukung dengan lokasi museum yang berada di kawasan cagar budaya sehingga bisa memberikan daya tarik lebih besar.

Menurut pengelolaannya, museum yang berada di wilyah DKI Jakarta terbagi dalam tiga bagian, yaitu ((Direktorat Museum Departemen Kebudayaan dan Pariwisata, 2008)):

1. Museum yang dikelola oleh Direktorat Museum Kebudayaan \& Pariwisata RI, di antaranya adalah Museum Nasional, Museum Naskah Proklamasi, Museum Kebangkitan Nasional, Museum Sumpah Pemuda dan Museum Basuki Abdullah.

2. Museum yang dikelola oleh Pemerintah DKI Jakarta, di antaranya adalah Museum Sejarah Jakarta, Museum Bahari, Museum Seni Rupa \& Keramik, Museum Wayang, Museum Taman Prasasti, Museum Juang, Museum Tekstil, Museum Husni Thamrin dan Museum Monumen Nasional.

3. Museum yang dikelola oleh Badan Usaha Milik Negara (BUMN), swasta atau perorangan, di antaranya adalah Museum Bank Mandiri, Museum Bank Indonesia, Museum POLRI, Museum Purna Bhakti, Museum Layang-Layang dan lainnya 
Pengelompokan museum dilakukan berdasarkan pada kumpulan bukti material manusia dan lingkungannya yang berkaitan dengan berbagai cabang seni, ilmu dan teknologi. Sedangkan yang dimaksud dengan museum khusus adalah museum yang menyimpan koleksi dari kumpulan bukti material manusia dan lingkungannya yang berkaitan dengan satu jenis koleksi baik itu seni, ilmu maupun teknologi (Direktorat Museum Departemen Kebudayaan dan Pariwisata, 2008).

Melalui koleksinya, museum harus dapat digunakan untuk menyampaikan pesan yang memuat berbagai nilai dan makna dari peradaban manusia. Jika pesan yang disampaikan belum dapat diterima oleh publik maka misi museum sebagai pusat informasi budaya belum sepenuhnya terwujud. Menurut Van Mensch (2003) via Ardiwidjaja (2013:35), fungsi dasar museum adalah melakukan penelitian, konservasi, dan komunikasi sebagai aspek mediasi terhadap masyarakat. Fungsi dasar tersebut disebut dengan istilah fungsi dasar museologi. Pengelolaan koleksi adalah serangkaian kegiatan yang menyangkut berbagai aspek kegiatan yang dimulai dari pengadaan koleksi, registrasi dan inventarisasi, perawatan, penelitian hingga koleksi tersebut disajikan di ruang pamer atau disimpan pada ruang penyimpanan.

Salah satu museum yang ada di Jakarta adalah Museum Bank Mandiri. Lokasi yang diperuntukan sebagai museum adalah bangunan yang berada di area Taman Stasiun Jakarta - Kota dan tercatat sebagai Bangunan Cagar Budaya berdasarkan SK Gubernur DKI Jakarta No.475 tahun 1993. Museum Bank Mandiri memiliki keunikan karena merupakan satu-satunya museum yang mempunyai sejarah panjang bukan hanya dari proses nasionalisasi bank milik Belanda, tetapi juga hasil dari merger beberapa bank yang membentuk Bank Mandiri.
Museum Bank Mandiri menempati sebuah bangunan dengan area seluas $10.039 \mathrm{~m}^{2}$ yang sebelumnya difungsikan sebagai kantor perbankan dan perdagangan yang berfokus pada sektor perkebunan. Gedung tersebut mulai dibangun tahun 1933 sebagai gedung Nederlandsche Handel-Maatschappij (NHM) di Hindia Timur yang kemudian lebih dikenal dengan nama de Factorij Batavia. Bangunan bergaya Nieuw Zakelijk atau Art Deco ini masih menggunakan struktur bangunan asli. Setelah NHM dinasionalisasi, bangunan ini difungsikan sebagai Kantor Pusat BKTN yang kemudian berubah menjadi kantor pusat Bank Exim hingga tahun 1994. Setelah terjadi proses merger anatara Bank Ekspor Impor Indonesia ( Bank Exim), Bank Dagang Negara (BDN), Bank Bumi Daya (BBD) dan Bank Pembangunan Indonesia (Bapindo) menjadi Bank Mandiri tahun 1999, bangunan ini kemudian difungsikan sebagai Museum Bank Mandiri (Mardiana, 2006).

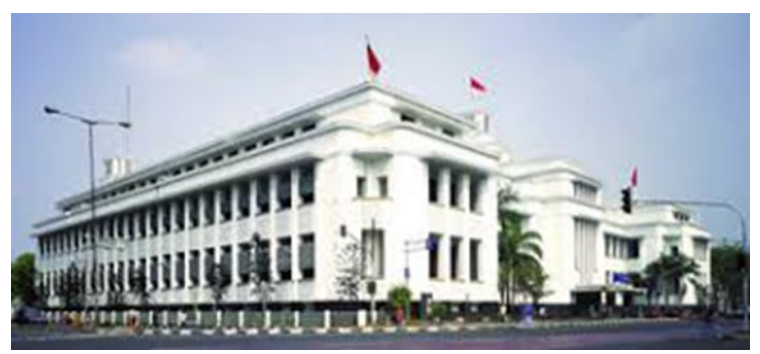

Gambar 1. Gedung Museum Bank Mandiri Sumber : Jakartalama (2010)

Berawal dari rangkaian sejarah bank pendahulu maupun bank-bank merger yang melebur menjadi Bank Mandiri, maka diperlukan upaya untuk menjaga agar rangkaian sejarah tersebut tidak terputus. Hal inilah yang melatarbelakangi pendirian sebuah museum perbankan. Bank Mandiri mendirikan sebuah museum perbankan yang memelihara dan merawat peninggalan budaya serta materi bankbank pendahulunya hingga menjadi Bank 
Mandiri. Koleksi tersebut diharapkan bermanfaat tidak saja untuk mengenang kembali nilai-nilai sejarah dan budaya yang terkandung didalamnya, tetapi juga sebagai pemicu kemajuan dunia perbankan nasional pada umumnya dan Bank Mandiri pada khususnya.

Sebagai bagian dari wisata edukasi perbankan, pengelola Museum Bank Mandiri tentunya harus memiliki kemampuan untuk mengelola koleksi yang ada di museum agar sesuai dengan maksud dan tujuan dari wisata edukasi. Pengelolaan yang dilakukan adalah dengan mengatur alur kunjungan serta menata koleksi museum sedemikian rupa sehingga memberikan kenyamanan dan kemudahan bagi pengunjung/wisatawan untuk memahami isi dan makna dari Museum Bank Mandiri. Pengaturan alur kunjungan dan penataan koleksi harus dilakukan dengan sistematis dan sejalan agar pengunjung dapat dengan mudah memaknai isi koleksi museum.

Kerangka pikir yang disusun oleh penulis dapat dilihat pada gambar di bawah ini.

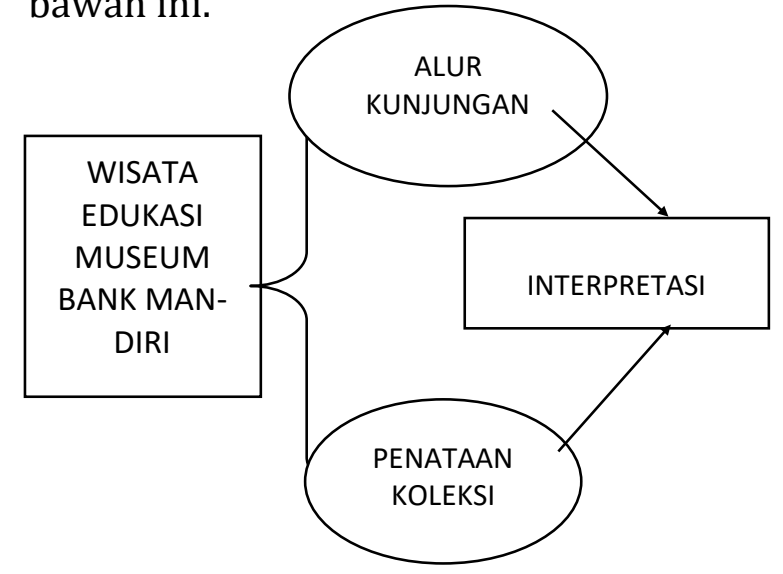

Gambar 2. Kerangka Pikir

Menurut Arbi, dkk. (2012), langkah -langkah penyusunan tata ruang museum adalah sebagai berikut:

a. Menentukan alur cerita (storyline) Yang dimaksud dengan alur cerita adalah sekumpulan dokumen atau blueprint yang menjadi acuan untuk menyusun materi museum agar dapat memiliki muatan pembelajaran dan pewarisan nilai. b. Menentukan alur pengunjung

Merupakan alur sirkulasi
pengunjung mulai dari pintu masuk
hingga pintu keluar dengan
memperhatikan konsep besaran
ruang.

Sedangkan untuk konsep alur penyajian atau penataan koleksi museum dapat menggunakan beberapa pendekatan sebagai berikut (Arbi, dkk. (2012)):

a. Pendekatan Kronologi

Penyajian koleksi secara kronologis dari waktu ke waktu dengan menempatkan benda koleksi dan informasi pendukungnya secara berurutan sesuai alur kunjungan dan juga linier dari fase awal hingga akhir.

a. Pendekatan Taksonomik

Penyajian koleksi yang memiliki kesamaan jenis serta berdasarkan pada kualitas, kegunaan, gaya, periode dan pembuat.

a. Pendekatan Tematik

Penyajian koleksi yang tidak menekankan pada objeknya, tetapi lebih menekankan pada tema dengan cerita tertentu.

a. Pendekatan Gabungan

Merupakan gabungan atau kombinasi dari pendekatan kronologi, taksonomik dan tematik.

Dari pemaparan tersebut maka penelitian ini memiliki tujuan sebagai berikut:

1. Mengetahui alur kunjungan di Museum Bank Mandiri serta penataan koleksinya

2. Mengetahui alur cerita (storyline) yang dibangun oleh Museum Bank Mandiri atas dasar penataan koleksinya.

3. Mengetahui jenis pendekatan yang dilakukan oleh Museum Bank Mandiri terhadap alur penyajian dan penataan koleksinya. 


\section{BAHAN DAN METODE PENELITIAN}

Penelitian berjudul "Konsep Penataan Koleksi Musem Untuk Mempermudah Pemahaman Wisatawan Dalam Wisata Edukasi Perbankan di Museum Bank Mandiri Jakarta" menggunakan penalaran induktif, yang diawali dengan pengumpulan data melalui pengamatan (observasi), wawancara (interview) dan studi pustaka. Data yang dikumpulkan kemudian dideskripsikan dan dievaluasi berdasarkan suatu kriteria yang diperoleh dari studi pustaka. Setelah itu dilakukan komparasi antara apa yang dilakukan oleh museum Bank Mandiri dengan konsep-konsep penataan koleksi museum yang diperoleh dari pustaka.

Alasan pemilihan lokasi di Museum

Bank Mandiri adalah sebagai berikut:

1. Museum yang mengangkat tema perbankan relatif masih jarang ditemui di Indonesia.

2. Museum Bank Mandiri memiliki latar belakang sejarah yang panjang yang berasal dari bank ex-kolonial Belanda yang kemudian berlanjut dengan bank nasional era pasca kemerdekaan Negara Republik Indonesia, gabungan/merger bankbank nasional, hingga menjadi Bank Mandiri saat ini.

3. Museum Bank Mandiri memiliki koleksi yang lengkap mengenai benda-benda perbankan dari masa kolonial hingga saat ini.

4. Museum Bank Mandiri merupakan cagar budaya yang berada di kawasan kota tua Jakarta, sehingga banyak dikunjungi oleh wisatawan yang ingin menikmati suasana masa lalu.

Tahapan penelitian yang dilakukan adalah sebagai berikut:

1. Pengumpulan data

a. Data dikumpulkan dengan cara observasi/pengamatan secara langsung terhadap alur kunjungan pengunjung dan penataan koleksi museum. b. Wawancara kepada narasumber, yaitu pengelola museum. Wawancara dilakukan untuk menyempurnakan hasil observasi, terutama untuk hal-hal yang terkait dengan pengelolaan alur kunjungan wisatawan serta penataan koleksi museum.

c. Studi pustaka, untuk mencari literatur mengenai lokasi penelitian dan literatur mengenai tata kelola alur kunjungan museum serta penataan koleksinya.

2. Deskripsi data

Mengumpulkan semua data yang sudah didapatkan, mengurai dan memilah data tersebut terutama yang terkait dengan alur kunjungan, alur penyajian koleksi serta penataannya.

3. Analisa data

Analisa data dilakukan dengan cara deskriptif komparatif yaitu dengan cara mendiskripsikan alur penyajian serta penataan koleksi di Museum Bank Mandiri. Kondisi tersebut kemudian dibandingkan dengan kondisi-kondisi ideal yang ada di pustaka.

\section{HASIL DAN PEMBAHASAN}

Museum Bank Mandiri yang terletak di Jalan Lapangan Stasiun Nomor 1 (Stationsplein 1 - Binnen Niuewpoortstraat) merupakan bangunan peninggalan masa kolonial yang berdiri di atas lahan seluas $10.039 \mathrm{~m}^{2}$. Arsitektur gedung berlantai empat seluas $21.509 \mathrm{~m}^{2}$ ini cenderung sederhana, berbentuk simetris dengan pintu masuk utama (main entrance) tepat berada di bagian tengah depan bangunan. Saat akan memasuki gedung museum, pengunjung harus menaiki sejumlah anak tangga menuju pintu masuk. Setelah sampai di lantai dasar, pengunjung akan berada dalam suatu ruangan besar dengan plafon tinggi serta meja counter teller yang 
sangat panjang ( \pm 122meter $)$ yang dilengkapi dengan ruang-ruang kerja terbuka di belakangnya.

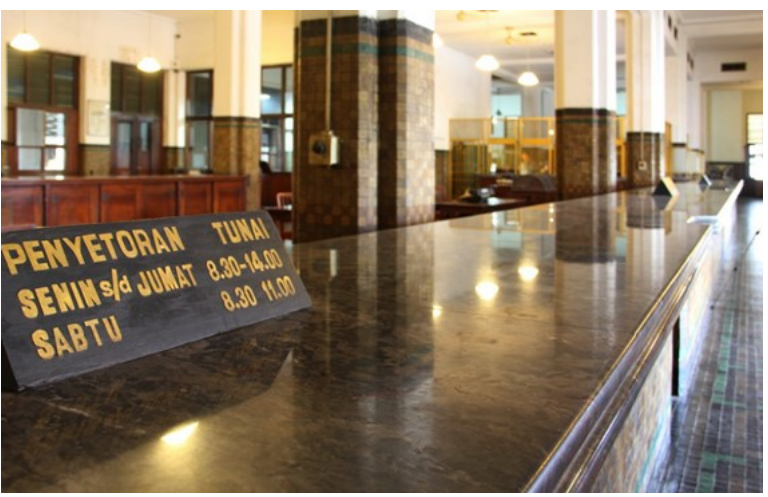

Gambar 3. Counter Teller Sumber : Indonesiakaya (2017)

Apabila dilihat dari bentuk bangunan dan penataannya, sebenarnya tidak ada alur baku bagi pengunjung dalam melakukan tour. Namun demikian, berdasar pengamatan penulis dan juga dari hasil wawancara dengan pengelola, sebagian besar kunjungan dimulai dari lantai dasar, kemudian dilanjutkan ke lantai 2 dan setelah itu turun kembali dua lantai untuk melihat koleksi yang ada di basement. Alur pengunjung di masingmasing lantai, adalah sebagai berikut:

1. Lantai Dasar

Di lantai dasar pengunjung dapat menyaksikan ruang layanan. Pada masa itu, layanan perbankan terbagi atas tiga counter yaitu counter untuk nasabah Belanda, counter untuk nasabah perkebunan terutama gula/tebu dan counter untuk nasabah beretnis Tionghoa yang menjadi golongan mayoritas dalam perdagangan/ekonomi. Pada masa tersebut kegiatan perbankan di dominasi oleh warga keturunan Belanda dan Tionghoa. Papan penunjuk menginformasikan aneka pelayanan bank di lantai basement dan lantai dasar. Misalnya untuk pelayanan effecten (efek atau surat berharga) dan safe deposit di sebelah kiri (dari sisi nasabah), sedangkan urusan perbankan di kanan. Di lantai dasar terdapat kantor inspektur gula (Suiker Bergcultuur Inspecteur) di sebelah kiri dan kantor direksi di sebelah kanan.

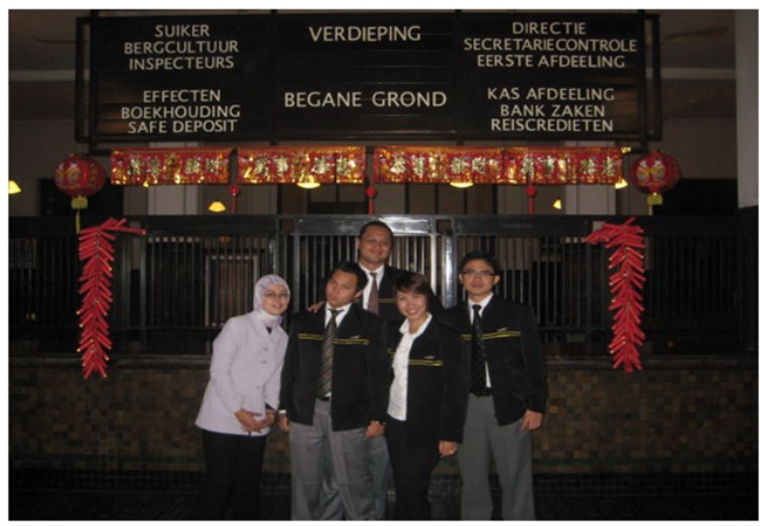

Gambar 4. Papan Petunjuk Informasi Layanan Sumber : Dokumentasi Pribadi

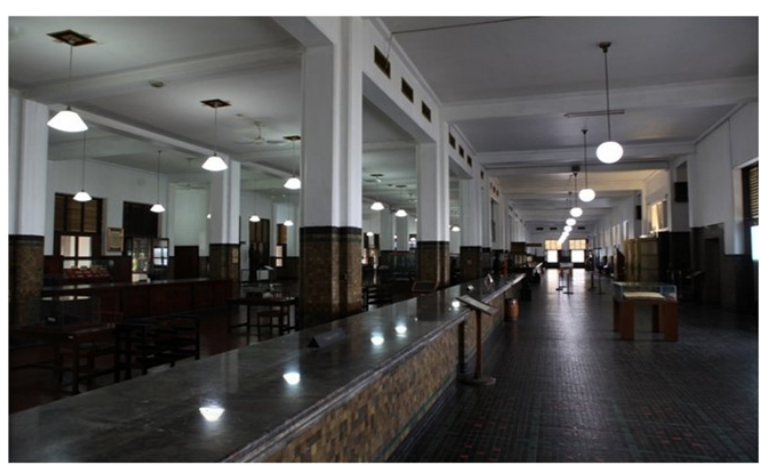

Gambar 5. Lantai Dasar yang Digunakan Untuk Pelayanan

Sumber : Megido (2017)

Lantai dasar terdiri dari ruang treasury (Kas Afdeeling), ruang pembukuan (kamar khusus untuk buku besar), dan ruang kasir China (Chineesche Kas). Di sayap selatan terdapat ruang perlengkapan bank, ruang kearsipan dan komunikasi serta ruang ATM. Di bagian belakang lantai dasar terdapat ruang back office yang dilengkapi dengan mesin hitung, mesin ketik, dan alat pencatatan ke buku besar. Di ujung sayap kiri, dipamerkan Buku Besar (Grootboek) yang digunakan untuk mencatat laporan keuangan NHM. Buku besar berukuran 38.5 X 49 X 17,3 $\mathrm{cm}^{3}$ dengan berat $20 \mathrm{~kg}$ yang terdiri dari 
1503 lembar berisi catatan tahun 1935-1936. Di ujung sayap kanan juga terdapat Buku Besar yang berukuran $67 \times 54 \times 13 \mathrm{~cm}^{3}$ dengan berat $28 \mathrm{~kg}$. Kedua buku ini ditulis dengan tulisan tangan miring yang sangat rapi.

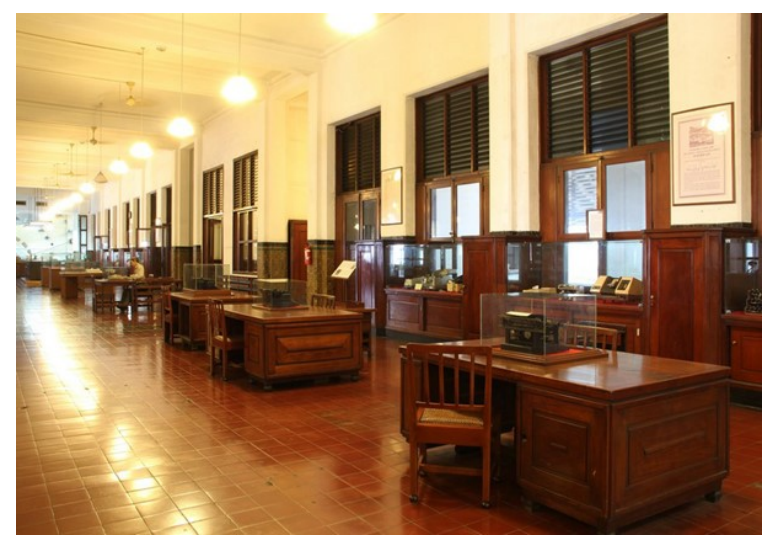

Gambar 6. Ruang Layanan Customer Sumber : Indonesiakaya (2017)

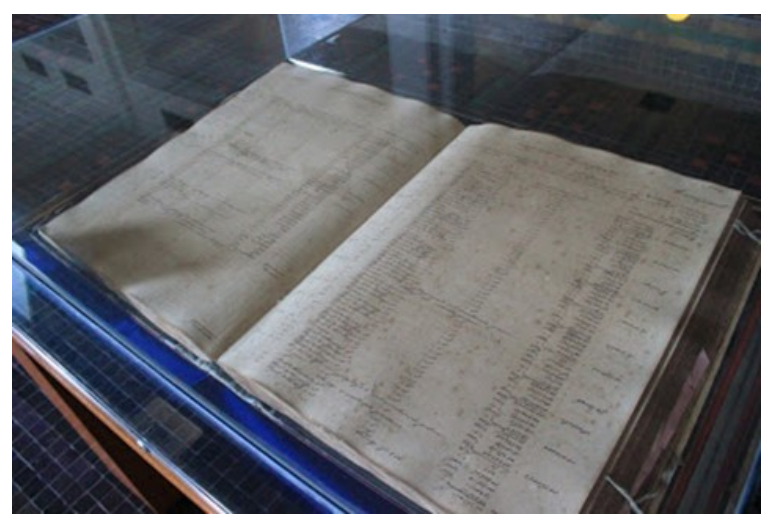

Gambar 7. Buku Besar di Ruang Layanan Sumber : Fachri (2013)

\section{Lantai I}

Setelah menaiki anak tangga dan sampai di lantai I, pengunjung akan memasuki ruang rapat besar. Saat menaiki tangga, pengunjung dapat melihat kaca mozaik yang menghiasi interior gedung. Mozaik tersebut menggambarkan empat musim yang ada di Belahan Eropa dan juga tokoh nakhoda kapal Belanda, Cornelis de Houtman. Di ruang rapat besar terdapat seperangkat meja dan kursi untuk keperluan rapat. Di dinding ruangan terlihat foto orang-orang penting di dunia perbankan Indonesia. Di pinggir ruangan dipamerkan pula mesin-mesin kuno yang dipergunakan dalam pelayanan nasabah seperti stempel timbul, penera bilyet, mesin hitung dan kalkulator kuno. Di ruangan ini juga perlihatkan mesin lift surat. Lift kecil seukuran buku ini menghubungkan antar lantai sehingga memudahkan perpindahan dokumen.

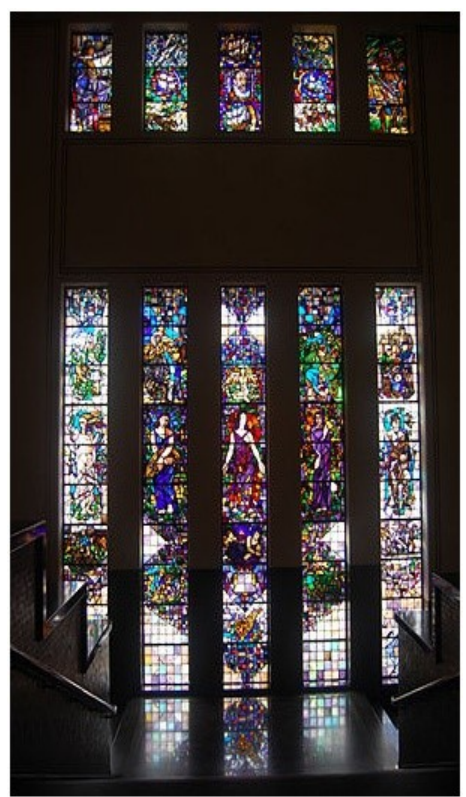

Gambar 8. Kaca Mozaik Yang Menunjukkan Empat Musim di Eropa Sumber : Wikipedia (2017)

Selain ruang rapat besar, di lantai I ini juga terdapat ruang direksi masa NHM. Di sini, pengunjung diperbolehkan untuk duduk di kursi direksi dan merasakan menjadi direktur bank NHM. Meninggalkan ruang direksi, terdapat ruang pamer uang-uang kertas Indonesia (numismatik). Berbagai koleksi uang yang pernah digunakan oleh masyarakat dari jaman ke jaman diperlihatkan di ruang ini.

Gambar 9. Ruang Rapat Yang Dihiasi oleh Foto Direksi

Sumber : Dokumentasi Pribadi 


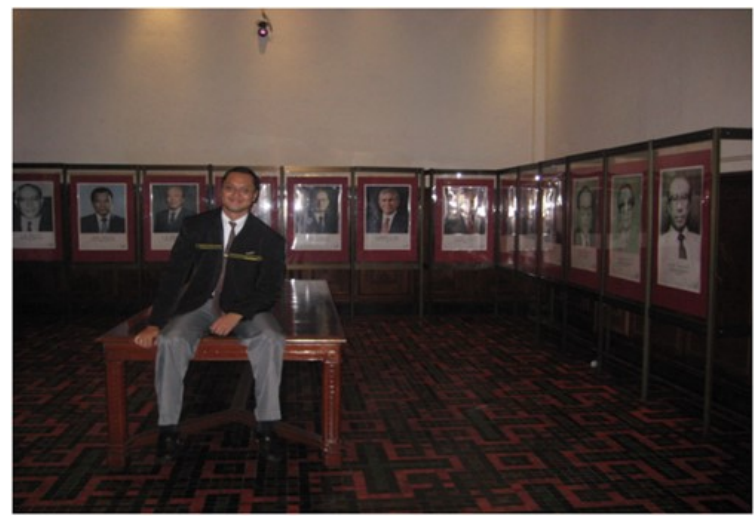

Gambar 9. Ruang Rapat Yang Dihiasi oleh Foto Direksi

Sumber : Dokumentasi Pribadi

3. Lantai basement

Di lantai bawah (basement) terdapat ruang kluis utama seluas sekitar $900 \mathrm{~m}^{2}$ dengan dinding luar setebal $1 \mathrm{~m}$ sebagai tempat penyimpanan uang kas, efek, maupun barang-barang berharga milik nasabah. Tiga galeri di ruang kluis atau khazanah adalah:

a. Effecten Kluis (ruang penyimpanan surat-surat berharga) seperti saham, obligasi, bilyet giro, deposito dan lain-lain. Semua tertulis dalam bahasa Belanda atau China. Pada ruangan tersebut pengunjung dapat melakukan aktivitas memotong kupon deposito.

b. $\quad$ Ruang Safe Deposit Box (SDB) yang berkapasitas 200 loker. Di ruang SDB terdapat ruang-ruang privat untuk nasabah saat menata barangbarang yang akan di simpan. Di sini juga terdapat ruang khusus untuk menyimpan emas batangan. Kunci SDB dipegang oleh dua pihak, yaitu nasabah dan bank sehingga untuk membuka kotak diperlukan akses keduanya. Pintu SDB juga sudah dilengkapi dengan pengatur waktu otomatis. Hal ini menunjukkan bahwa teknologi sudah diterapkan pada masa itu. Pintu SDB dipesan langsung dari Belanda dengan berat sekitar 5 ton.

c. Kast Kluis (ruang penyimpanan uang). Pada ruang tempat penyimpanan uang (kast kluis)

pengunjung dapat merasakan

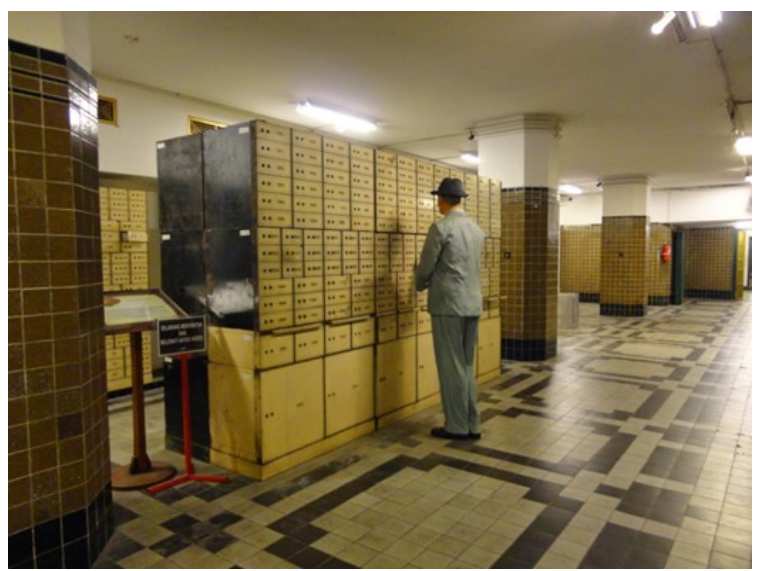

Gambar 10. Ruang Safe Deposit Box (SDB) Sumber : The History Explorer Jakarta (2014)

mengangkat dan mengangkut uang di dalam peti kayu. Alat pengangkut uang tersebut ada yang berbentuk tandu dan ada pula yang sudah beroda. Uang yang digunakan adalah uang buatan/replika yang sudah disesuaikan dengan jamannya. Khasanah uang ini sangat luas dengan lemari-lemari uang menempel di sekeliling dinding. Di belakang meja petugas terdapat lemari arsip catatan keluar masuknya uang tunai.

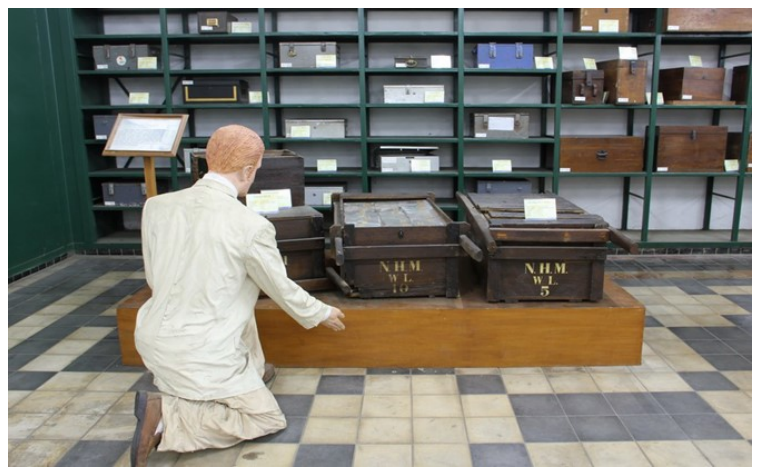

Gambar 11. Peti Uang

Sumber : Indonesiakaya (2017)

Dari desain yang ada, nampak bahwa sistem keamanan bank sudah dirancang secara modern. Ruang Kluis memiliki keistimewaan tersendiri karena dilengkapi dengan pintu baja yang besar, 
kuat, memiliki kunci kombinasi serta ditempatkan dalam suatu ruang khusus yang tidak mudah dilalui. Dari Kast Kluis, terdapat pintu keluar menuju taman.

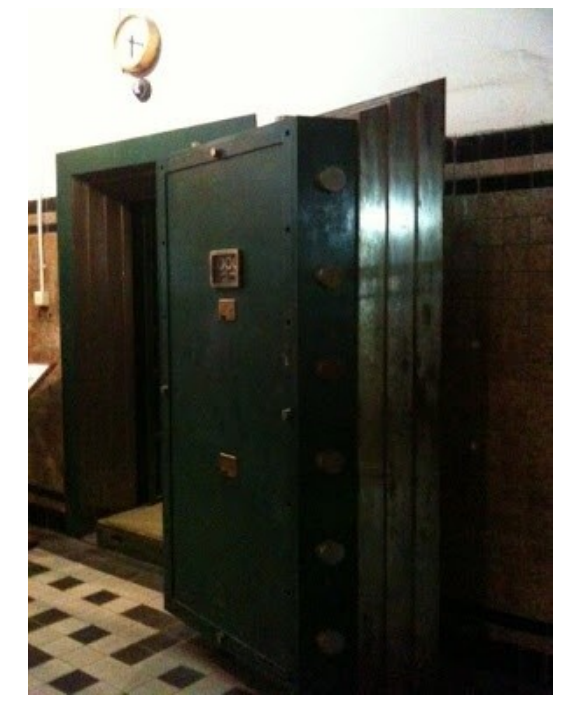

Gambar 12. Pintu Baja

Sumber : Hartono (2011)

Apabila dilihat dari pengaturan alur kunjungan, penulis berpendapat bahwa alur cerita (storyline) yang dibangun oleh Museum Bank Mandiri adalah pembelajaran dalam memahami sistem operasional bank dan juga pelayanannya. Beberapa jenis alur cerita (storyline) yang dapat dimunculkan adalah:

1. Alur pembelajaran pelayanan bank. Pelayanan bank dilakukan di kantor depan (front of ice) dimana nasabah dapat berinteraksi langsung dengan petugas untuk menyampaikan jenis layanan yang dikehendaki. Jenis layanan tersebut adalah layanan perbankan (tarik setor uang, pembukaan rekening dan pengajuan kredit), pembukaan pelayanan effecten (efek atau surat berharga) serta layanan safe deposit. Nasabah akan lebih mudah dalam memilih jenis layanan karena saat pertama kali masuk ke dalam bank nasabah dapat melihat papan petunjuk arah jenis layanan yang dikehendaki. Pengunjung museum dapat melihat langsung ke mana arah yang harus dituju oleh nasabah, lokasi tempat bertransaksi dan juga fasilitas/alat yang tersedia untuk bertransaksi. Hal ini menunjukkan bahwa pada masa itu perbankan sudah mengutamakan model pelayanan yang nyaman dan menyenangkan bagi nasabahnya.

2. Alur pembelajaran operasional bank. Di Museum Bank Mandiri, pengunjung juga dapat mengetahui alur operasional yang terjadi setelah bank menerima permintaan layanan dari nasabah. Permintaan nasabah dapat langsung ditindaklanjuti ke unit terkait. Beberapa unit pendukung (supporting unit/back office) masih berada di lantai yang sama dengan unit layanan. Hal ini ditunjukkan dengan adanya beberapa meja, kursi dan peralatan yang berada di belakang counter layanan. Salah satu contoh alur operasional yang dapat dilihat langsung adalah alur pengajuan kredit yang diproses oleh beberapa staf terkait yang masih berada dalam satu lantai. Apabila nasabah ingin menggunakan layanan yang terkait layanan penyimpanan maka nasabah dapat berjalan turun ke basement untuk menyimpan barang berharganya di safe deposit box. Pengunjung dapat melihat langsung dimanakah letak safe deposit box, brankas uang untuk menyimpan seluruh uang tunai di bank di akhir hari serta tempat untuk menyimpan surat dan dokumen berharga. Buku harian untuk pencatatan keluar masuknya uang di brankas juga masih dapat dilihat secara langsung.

Operasional bank tentunya juga terkait dengan aspek manajerial. Di Museum Bank Mandiri, pengunjung dapat melihat tempat duduk direksi/pimpinan bank, manager, supervisor, dan staff dari masingmasing unit kerja sehingga dapat 
membayangkan bagaimana alur perintah dan mekanisme operasional yang berlangsung antar bagian. Buku besar yang masih asli yang dapat menjadi petunjuk jumlah dan kapasitas transaksi saat itu juga masih tersimpan dengan baik dan dapat disaksikan secara langsung.

3. Alur pembelajaran dokumen dan surat berharga dari masa ke masa. Di Museum Bank Mandiri pengunjung dapat melihat jenis dokumen dan surat berharga seperti saham, obligasi, bilyet giro dan deposito dari masa ke masa. Hal ini menunjukkan bahwa pada saat itu mayarakat sudah menjadikan bank sebagai sarana untuk berinvestasi sehingga bank memiliki peran penting dalam menggerakkan roda perekonomian pada saat itu.

4. Alur pembelajaran fasilitas dan peralatan bank dari masa ke masa. Sebagai sebuah lembaga keuangan, tentunya bank juga harus dilengkapi dengan fasilitas pendukung untuk memperlancar proses operasional dan juga layanannya. Di Museum Bank Mandiri, pengunjung dapat menyaksikan alat-alat yang digunakan untuk bertransaksi pada jaman dahulu hingga sekarang. Peralatan tersebut antara lain mesin ketik, peti uang, mesin hitung uang mekanik, kalkulator, mesin pembukuan, mesin cetak, alat press bendel, seal press, bermacammacam stempel, dan mesin ATM. Keberadaan alat-alat ini menunjukkan bahwa pada saat itu bank sudah memikirkan dan menerapkan pola kerja yang efisien dengan memanfaatkan penggunaan alat serta berupaya semaksimal mungkin untuk mempercepat layanannya terhadap nasabahnya.

5. Alur pembelajaran jenis dan bentuk mata uang dari masa ke masa. Di Museum Bank Mandiri, pengunjung dapat menyaksikan jenis uang kertas dan koin yang pernah beredar di Indonesia dari masa ke masa. Hal ini menunjukkan bahwa penggunaan uang sebagai sarana pembayaran yang sah sudah dilakukan sejak jaman dulu. Bentuk dan gambar uang yang beredar menyesuaikan dengan masanya masing-masing.

Dari pengamatan penulis, pendekatan penataan koleksi yang dilakukan oleh pengelola Museum Bank Mandiri adalah dengan pendekatan gabungan, yaitu kombinasi dari pendekatan kronologis, taksonomik dan tematik. Penjelasan dari pendekatan tersebut adalah sebagai berikut:

1. Pendekatan Tematik

a. Pendekatan tematik dilakukan pada lantai dasar dimana suasana yang ditonjolkan adalah suasana pelayanan di bank pada masa lalu dengan fasilitas dan peralatan layanan yang masih lengkap. Pengunjung dapat merasakan alur sebagai nasabah pada masa tersebut mulai dari memasuki pintu utama, melihat papan penunjuk arah jenis layanaan, bertransaksi di counter teller yang berteralis, melakukan pengurusan kredit di bagian back of 6 ice, serta saat mendapatkan pelayanan untuk penyimpanan barang/surat berharga di Safe Deposit Box.

b. Pendekatan tematik juga dilakukan untuk menceritakan proses operasional back of 6 ice/ supporting sehingga pengunjung bisa mengetahui proses yang dilakukan pihak bank setelah mendapatkan input transaksi/ permohonan/perintah dari nasabah yang dilayani di bagian pelayanan (front of 6 ice), 
contohnya adalah alur proses kredit, alur keluar/masuk uang kas hingga sampai ke Kast Kluis di akhir hari, serta alur proses penerbitan surat berharga.

c. Pendekatan tematik dilakukan di basement, yaitu pada atraksi mengangkat dan memindahkan uang keluar masuk kast kluis dengan menggunakan alat pengangkut berbentuk tandu maupun yang beroda. Atraksi ini akan memperlihatkan dan memberikan pelajaran bagaimana proses pengelolaan uang kas pada masa itu yang cukup kompleks dan banyak jumlahnya mengingat pada masa itu belum terdapat transaksi online.

d. Pendekatan tematik untuk ruang layanan nasabah Tionghoa (Chineesche Kas), mengingat pada masa tersebut warga negara keturunan Tionghoa diberikan ruang kas khusus untuk melakukan transaksi. Dari manekin yang dipajang, nampak bahwa pekerja yang dipekerjakan oleh pihak bank adalah pekerja yang juga beretnis Tionghoa. Pada masa tersebut kegiatan perbankan di dominasi oleh warga keturunan Belanda dan Tionghoa sebagaimana aturan yang ditetapkan oleh Pemerintah Belanda.

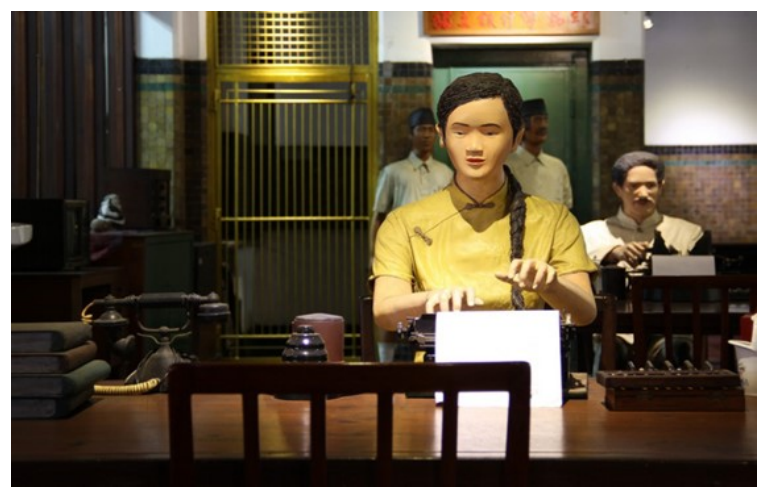

Gambar 13. Ruang Layanan Nasabah Tionghoa Sumber : Indonesiakaya (2017)
1. Pendekatan Taksonomik

Pendekatan taksonomik dapat dilihat pada beberapa jenis koleksi sejenis atau memiliki fungsi yang sama ditata dengan baik dan rapi di satu titik lokasi. Beberapa contoh koleksi yang ditata secara taksonomik adalah:

a. Mesin ketik

Sebelum era pengetikan dengan komputer seperti saat ini, bank menggunakan mesin ketik manual untuk segala macam bentuk penyajian laporan transaksi keuangan, pencatatan dan juga penulisan di surat berharga. Museum Bank Mandiri berupaya untuk memunculkan kembali peran mesin ketik manual terhadap perkembangan usaha jasa perbankan pada saat itu.

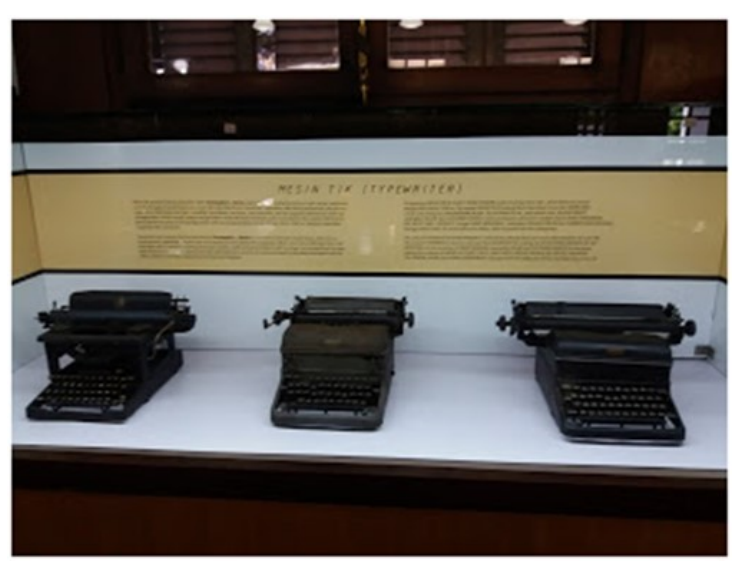

Gambar 14. Koleksi Mesin Ketik

Sumber : Hardiansyah, A., et.al. (2017)

b. Alat penghitung uang

Sebagai lembaga jasa keuangan tentunya bank selalu berhubungan dengan uang fisik baik kertas maupun logam. Untuk menghitung uang kertas dalam jumlah besar, petugas kasir biasanya menggunakan alat bantu berupa alat hitung otomatis untuk mempermudah penghitungan dan mempercepat waktu layanannya. 


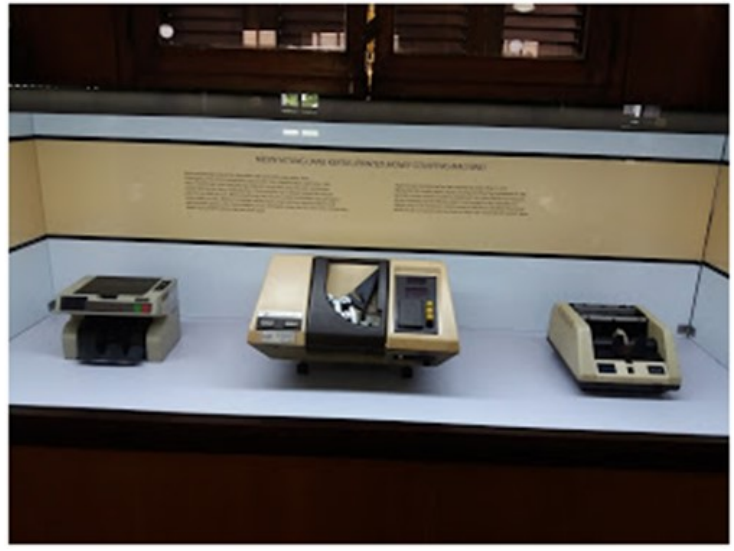

Gambar 15. Mesin Hitung Uang Sumber : Hardiansyah, A., et.al. (2017)

c. Penera / stempel bilyet. Stempel digunakan untuk mengesahkan surat termasuk surat berharga. Bahan yang dugunakan adalah logam, kayu, atau karet elastis. Pada saat itu stempel yang akan digunakan harus diberi tinta terlebih dahulu untuk kemudian ditempelkan pada kertas yang akan distempel.

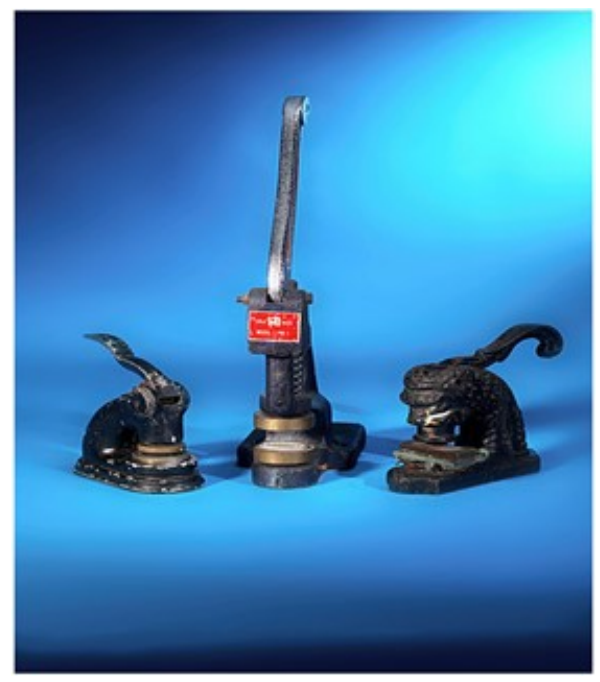

Gambar 16. Penera Stempel / BilyetSumber : Museum Bank Mandiri (2017)

d. Brandkast.

Sebagai suatu lembaga jasa keuangan di masa yang masih belum on-line seperti saat ini, bank tentunya membutuhkan ruang penyimpanan besar yang aman untuk menyimpan uang kas pada setiap harinya. Untuk itu maka bank akan selalu menyediakan brandkast yang terbuat dari besi/baja dengan ukuran besar yang sulit untuk di akses oleh orang-orang yang tidak memiliki otoritas.

e. Buku besar.

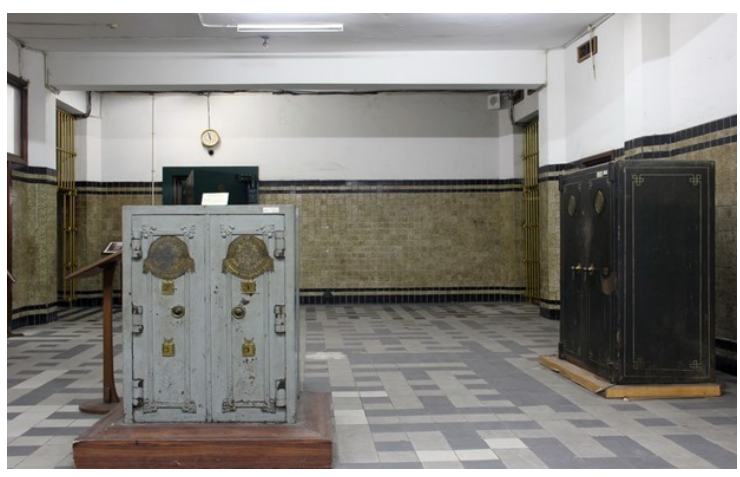

Gambar 17. Brankas

Sumber : Indonesiakaya (2017)

Buku besar adalah buku utama yang merangkum catatan semua transaksi keuangan. Buku besar digunakan sebagai dasar untuk membuat laporan neraca dan laporan laba rugi (L/R). Buku besar merupakan buku yang memuat akun-akun yang sudah dicatat baik dalam jurnal. Di Museum Bank Mandiri terdapat 45 buah buku besar yang berbahasa Belanda. Buku besar ini berisi perincian mengenai perkiraan perubahan debet dan kredit yang dilaporkan setiap akhir bulan.

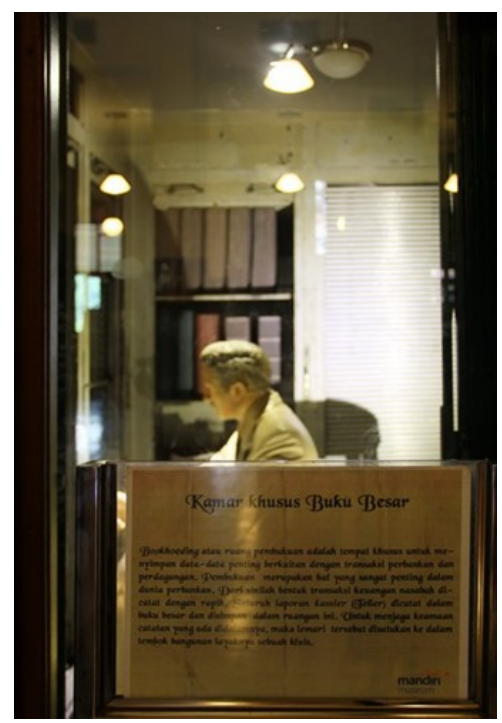

Gambar 18. Ruang koleksi buku besar Sumber : Indonesiakaya (2017) 


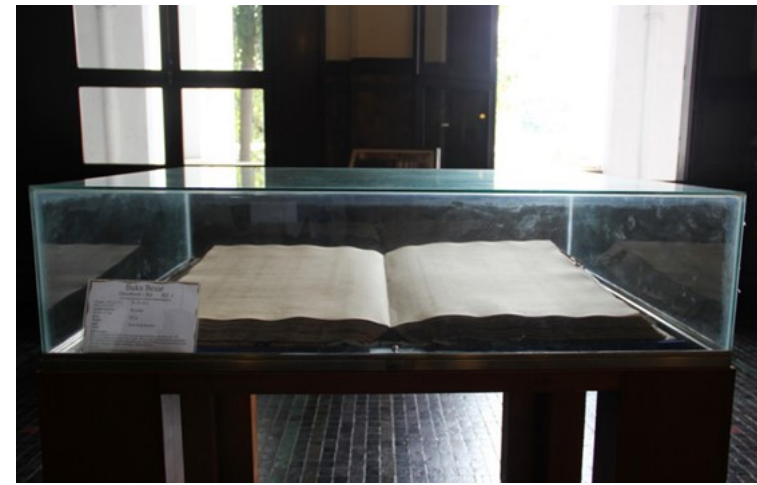

Gambar 19. Buku Besar Pertama Sumber : Indonesiakaya (2017)

f. Alat pemotong kertas

Sebagai suatu lembaga layanan jasa keuangan, bank tentunya banyak menerbitkan surat berharga dan surat-surat penting. Alat pemotong kertas diperlukan untuk memotong dan merapikan kertas sesuai ukuran yang diinginkan, menekan tumpukan kertas dan memadatkan kertas yang berbentuk jilidan.

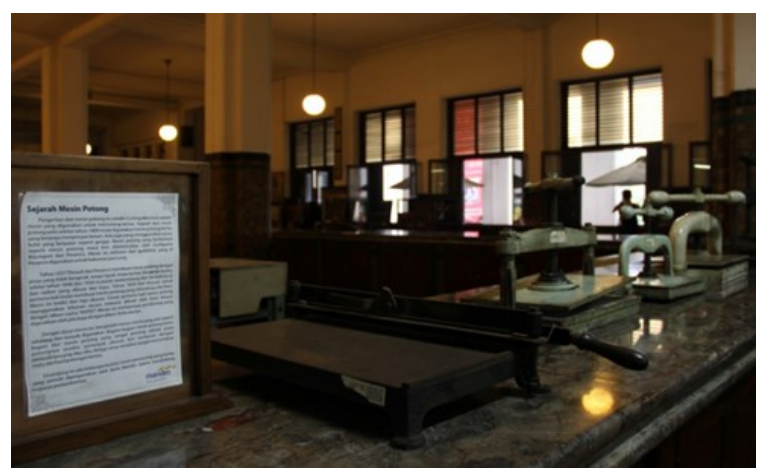

Gambar 20. Koleksi Alat Pemotong Kertas Sumber : Indonesiakaya (2017)

g. Peti uang

Peti uang berukuran kecil biasa digunakan oleh kasir-kasir di meja layanan untuk meletakkan uang kas yang sudah dialokasikan kepada masing-masing kasir, dan juga untuk menyimpan uang hasil transaksi harian. Saat sudah memasuki akhir waktu layanan dan operasional, mereka memindahkan uang hasil transaksi harian tersebut dari tempat kerja masing-masing menuju brandkast dengan menggunakan peti uang. Sedangkan peti uang berukuran besar digunakan oleh pihak bank untuk mengangkut uang dalam jumlah besar ke tempat lain, misalkan ke kantor cabang atau ke nasabah.

h. Surat berharga

Beberapa jenis surat berharga yang ditampilkan di Museum Bank Mandiri antara lain, wesel, promes, cek, bilyet giro, obligasi, sertifikat bank, garansi bank dan lain sebagainya.

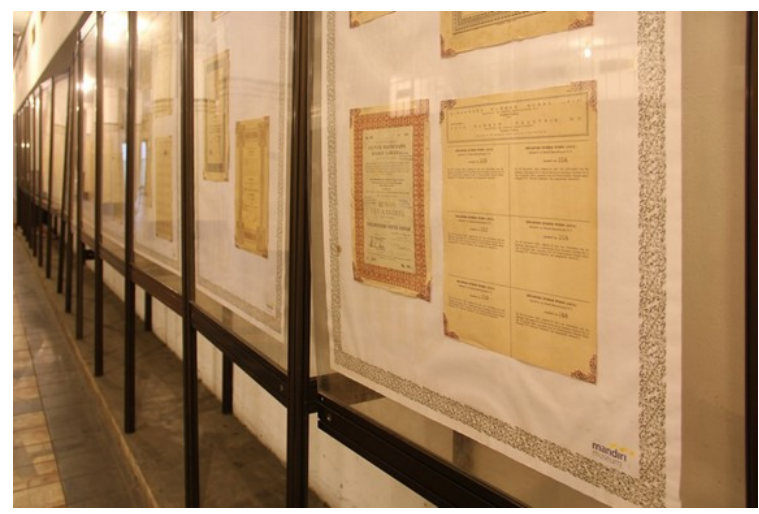

Gambar 21. Koleksi Surat Berharga Sumber : Indonesiakaya (2017)

i. Mesin ATM (Anjungan Tunai Mandiri)

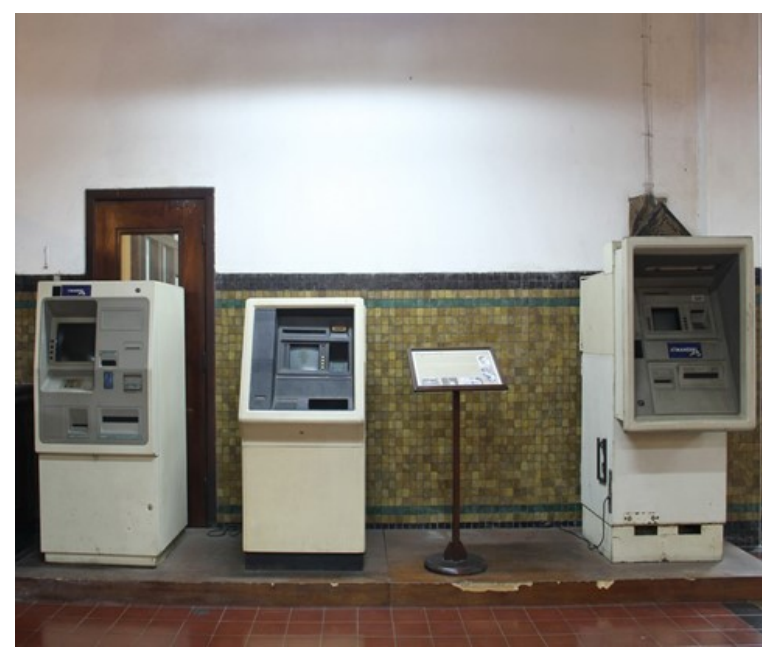

Gambar 22. Koleksi Mesin ATM Sumber : Indonesiakaya (2017)

ATM adalah alat yang berfungsi untuk melakukan penarikan tunai dengan menggunakan fasilitas mesin. Di Museum Bank Mandiri terdapat empat buah mesin ATM 
lama yang berasal dari beberapa periode waktu.Di lokasi cluster mesin ATM terdapat papan petunjuk yang menjelaskan empat tokoh penemu mesin ATM generasi pertama, yaitu Donal Wetzel (penemu mesin ATM), James Goodfellow ( penemu sistem PIN di tahun 1966) dan John ShepherdBarron (penemu mesin ATM periode Modern).

j. Server

Server merupakan komputer yang berfungsi untuk mengatur sistem jaringan komputer. Server merupakan induk dari semua komputer yang terhubung di system bank. Server memiliki fungsi untuk menangani penyimpanan, pengolahan, pendistibusian data secara terpusat, serta berfungsi sebagai pusat aplikasi bersama (shared). Server merupakan salah satu koleksi yang ada di Museum Bank Mandiri yang berasal dari era awal teknologi.

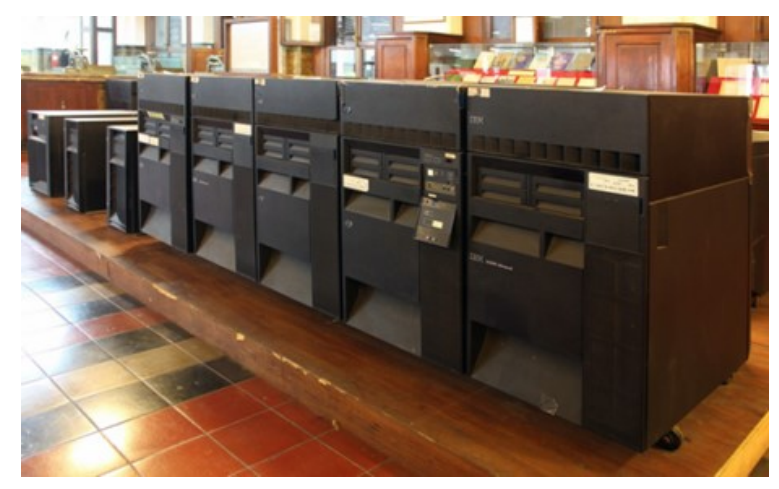

Gambar 23. Koleksi Server

Sumber : Indonesiakaya (2017)

\section{k. Foto direktur}

Di lantai I, terdapat ruang rapat direksi pada masa lalu yang dilengkapi dengan foto direktur utama sejak jaman NHM hingga saat ini sehingga pengunjung dapat mengetahui siapa saja yang pernah menjidi direktur bank di era NHM, bank merger dan Bank Mandiri.

l. Sepeda kuno

Koleksi sepeda kuno merupakan koleksi tambahan yang ada di Museum Bank Mandiri yang pernah menjadi alat transportasi favorit yang banyak digunakan oleh masyarakat pada masa tersebut.

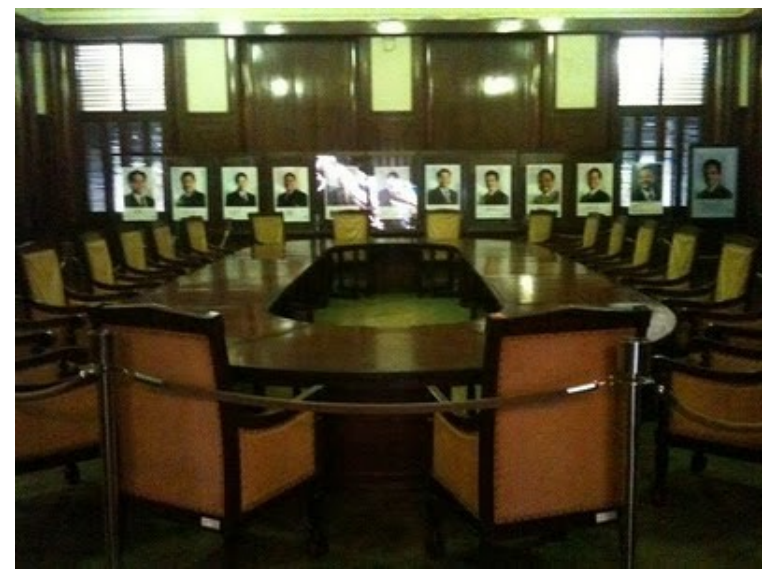

Gambar 24. Koleksi Foto Direktur Sumber : Fachri (2013)

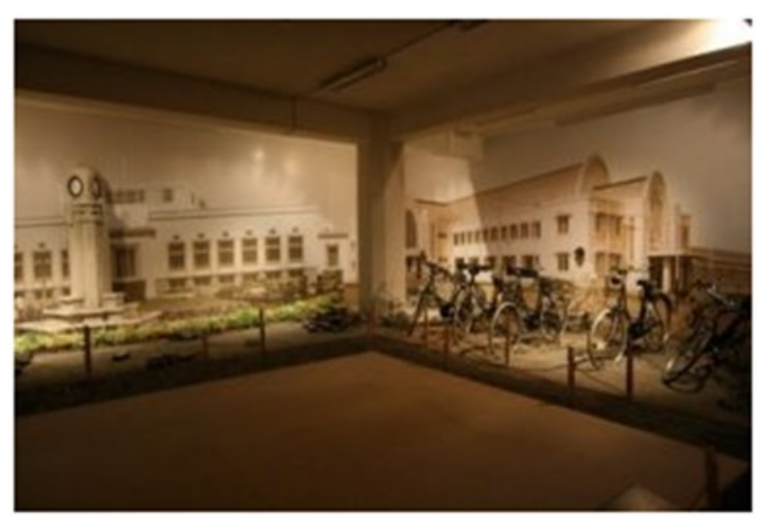

Gambar 25. Koleksi Sepeda Kuno Sumber : Jakartalama (2010)

2. Pendekatan Kronologis

Sesuai kurun waktunya, koleksi Museum Bank Mandiri dapat dikelompokkan berasarkan periode bank-bank pendahulu mulai tahun 1826-1959/1960 dengan koleksi berasal dari masa NHM, Escomptobank, NIHB/NHB dan BIN, periode bank-bank bergabung tahun 1959/1960-1998 (masa BBD, BDN, Bank Exim dan Bapindo), serta periode awal merger Bank Mandiri sampai dengan go public tahun 1999-2003. Beberapa jenis koleksi yang dikelompokkan dengan pendekatan kronologis antara lain: 
a. Mesin ketik

Koleksi mesin ketik yang dimiliki oleh Museum bank mandiri tergolong lengkap. Hampir semua jenis koleksi mesin ketik lama yang dipakai sejak jaman NHM hingga masa generasi terakhir sebelum era komputer dipamerkan di museum ini. Setiap mesin ketik yang dipamerkan dilengkapi dengan tahun penggunaannya. Beberapa merk mesin ketik ternama pada saat itu seperti Brother, Royal dan Olivetti dapat dijumpai di museum ini.

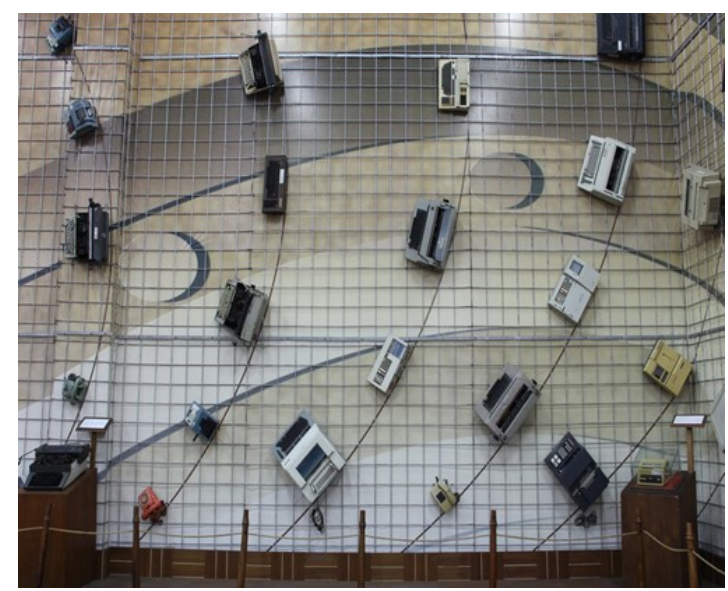

Gambar 26. Koleksi Mesin Ketik Dari Berbagai Masa

Sumber : Indonesiakaya (2017)

b. Mesin ATM

Mesin ATM yang dipamerkan di Museum Bank Mandiri telah dilengkapi juga dengan tahun pembuatan dan juga penciptanya. Dengan demikian pengunjung dapat mengetahui kapan mesin ATM tersebut dioperasionalkan. Pada awalnya mesin ATM hanya berfungsi untuk penarikan tunai sehingga peran ATM hanya sekedar untuk menggantikan petugas kasir. Berbeda dengan kondisi saat ini dimana mesin ATM juga berfungsi untuk berbagai macam transaksi nontunai. Gambar mesin ATM dapat dilihat pada Gambar 22. c. Foto direktur

Untuk menambah wawasan pengunjung tentang pimpinan/ pejabat/direksi bank sejak era NHM hingga Bank Mandiri saat ini, pengelola museum juga memajang koleksi foto direktur lengkap dengan informasi tahun serta masa jabatannya. Koleksi foto ini dipajang di ruang rapat direksi di lantai I. Gambar foto direktur dapat dilihat pada Gambar 24.

\section{KESIMPULAN}

Beberapa jenis alur cerita (storyline) yang dibangun dan dimunculkan oleh Museum Bank Mandiri adalah alur pembelajaran pelayanan bank, alur pembelajaran operasional bank, alur pembelajaran dokumen dan surat berharga dari masa ke masa serta alur pembelajaran fasilitas dan peralatan bank dari masa ke masa. Sedangkan untuk penataan koleksi, Museum Bank Mandiri menggunakan pendekatan gabungan dari tiga pendekatan, yaitu pendekatan tematik, pendekatan taksonomik, dan pendekatan kronologi.

\section{DAFTAR PUSTAKA}

Arbi, Yunus. 2012. Konsep Penyajian Museum, bagian 4. <https:// museumku.wordpress.com/ 2012/02/05/konsep-penyajianmuseum-bagian-4/> (Di akses tanggal 23 Januari 2018)

Ariwidjaja, Roby. 2013. Pengembangan Daya Tarik Museum. Yogyakarta: Amara Books.

Direktorat Jenderal Sejarah dan Purbakala. 2007. Pengelolaan Koleksi Museum. Direktorat Jenderal Sejarah dan Purbakala. 
Darmastuti, Farikha R. 2016. Daya Tarik Koleksi dan Persepsi Pengunjung Pada Museum Sandi Yogyakarta. Skripsi. Universitas Gadjah Mada : Yogyakarta.

Dinas Komunikasi, Informatika dan Statistik Pemerintah Provinsi Jakarta . 2017. Jumlah Kunjungan Wisatawan ke Museum di Lingkungan Dinas Kebudayaan dan Pariwisata Jakarta tahun 2015. < http://data.jakarta.go.id/eu/ dataset/data-jumlah-wisatawanpengunjung-museum/ resource/0c6561c0-f6dd-4a0a8f7a-384e8a62dbd8> (Di akses tanggal 23 Januari 2018)

Direktorat Museum Departemen Kubudayaan dan Pariwisata. 2008. Pedoman Museum Indonesia. Departemen Kebudayaan dan Pariwisata.

Fachri, H.S. 2013. Wisata Sejarah:Peralatan kuno di Museum Bank Mandiri. <http://aneka10. blogspot. co.id/2013/02/wisatasejarahperalatan-kuno-dimuseum.html.> (Di akses tanggal 28 Januari 2018)

Hartono, Sony. 2011. Mueseum Bank Mandiri. http:// www.polahku.com/2011/02/ museum-bank-mandiri.html (Di akses tanggal 28 Januari 2018)

Indonesiakaya. 2017. Jejak Rekam Perbankan Nasional di Museum Bank Mandiri. <https://www. indonesiakaya.com/jelajahindonesia/detail/jejak-rekamperbankan-nasional-di-museumbank-mandiri> (Di akses tanggal 28 Januari 2018)

Jakartalama. 2010. Museum Bank Mandiri. $<$ https:// jakartalama.wordpress.com/2010/ 09/25/ museum-bank-mandiri/> (Di akses tanggal 28 Januari 2018)

Kompas. 2017. Warga Bingung Saat Ditanya Anies Berapa Jumlah Museum di Jakarta. < http:// megapolitan.kompas.com/ read/2016/11/10/20092221/ warga.bingung.saat.ditanya.anies. berapa. jumlah.museum.di.jakarta> (Di akses tanggal 23 Januari 2018)

Mardiana, Intan (ed). 2006. Museum Bank Mandiri. (Menapak Sejarah Menyongsong Masa Depan). Jakarta : Bank Mandiri Press.

Megido, Yanuar. 2017. 10 Foto Museum Bank Mandiri. Jakarta Kota Tua, Sejarah Angker + Alamat Denah. < https://www.jejakpiknik.com/ museum-bank-mandiri/> (Di akses tanggal 28 Januari 2018)

The History Explorer Jakarta. 2014. Because, There is No Time Machine To Go Back To Your Country History. < http:// historyexplorerjkt.blogspot.co.id/2 014/10/museum-bankmandiri.html.> (Di akses tanggal 28 Januari 2018)

Wikipedia. 2017. Museum Bank Mandiri. $<$ https://id.wikipedia.org/wiki/ Museum Bank Mandiri> (Di akses tanggal 28 Januari 2017) 